Maya Grigorievna Lyapina ${ }^{1}$

Maria Dencheva ${ }^{2}$

Assya Krasteva-Panova ${ }^{2}$

Mariana Tzekova-Yaneva ${ }^{2}$

Mariela Deliverska ${ }^{3}$

Angelina Kisselova-Yaneva ${ }^{2}$

\title{
CONCOMITANT SENSITIZATION TO GLUTARALDEHYDE AND METHACRYLIC MONOMERS AMONG DENTISTS AND THEIR PATIENTS
}

\author{
WSPÓŁISTNIEJĄCE UCZULENIE NA ALDEHYD GLUTAROWY \\ I MONOMERY METAKRYLANOWE U STOMATOLOGÓW I ICH PACJENTÓW
}

\author{
${ }^{1}$ Medical University, Sofia, Bulgaria \\ Faculty of Medicine, Department of Hygiene, Medical Ecology and Nutrition \\ ${ }^{2}$ Medical University, Sofia, Bulgaria \\ Faculty of Dental Medicine, Department of Oral and Image Diagnostic \\ ${ }^{3}$ Military Medical Academy, Sofia, Bulgaria \\ Legal Department
}

\begin{abstract}
Background: A multitude of methacrylic monomers is used in dentistry. Glutaraldehyde (G) is used in dental practice and consumer products as a broad-spectrum antimicrobial agent. The purpose of our study is to evaluate the frequency and the risk of concomitant sensitization to some methacrylic monomers (methyl methacrylate (MMA), triethyleneglycol dimethacrylate (TEGDMA), ethyleneglycol dimethacrylate (EGDMA), 2,2-bis-[4-(2-hydroxy-3-methacrylo-xypropoxy)phenyl]-propane (Bis-GMA), 2-hydroxy-ethyl methacrylate (2-HEMA) and tetrahydrofurfuryl methacrylate (THFMA)) and glutaraldehyde in students of dentistry, students from the dental technician school, dental professionals and dental patients. Material and Methods: A total of 262 participants were included in the study: students of dentistry, students from the dental technician school, dental professionals, and dental patients as a control group. All were patch-tested with methacrylic monomers and glutaraldehyde. The results were subject to the statistical analysis $(\mathrm{p}<0.05)$. Results: Among the group of dental students, the highest frequency of concomitant sensitization was to TEGDMA and G (15.5\%). In the group of patients the highest frequency of concomitant sensitization was to EGDMA and G (16.4\%). The frequency of concomitant sensitization among dental professionals was much lower, with the highest rate to TEGDMA and G (7.7\%), too. We consider the students from the dental technician school, where the exposure to glutaraldehyde is less likely, to be the group at a lesser risk of concomitant sensitization. Conclusions: Dental students and dental patients could be outlined as groups at the risk of concomitant sensitization to glutaraldehyde and methacrylic monomers. For dental professionals, we assumed an increased risk for concomitant sensitization to TEGDMA and aldehydes that are commonly used in dentistry. We consider the students from the dental technician school to be the group at a lesser risk of concomitant sensitization to glutaraldehyde and methacrylic monomers. Med Pr 2016;67(3):311-320
\end{abstract}

Key words: dental professionals, glutaraldehyde, concomitant contact sensitization, methacrylic monomers, students of dental medicine, students of dental technician school

\section{STRESZCZenie}

Wstęp: W stomatologii stosuje się wiele monomerów metakrylanowych, a także aldehyd glutarowy (G), który wchodzi w skład powszechnie dostępnych wyrobów jako środek przeciwbakteryjny. Celem badania była ocena częstości i ryzyka współistniejącego uczulenia u studentów stomatologii, uczniów technikum dentystycznego, lekarzy stomatologów i pacjentów gabinetów dentystycznych na aldehyd glutarowy i niektóre monomery metakrylanowe (metakrylan metylu (methyl methacrylate - MMA), dimetakrylan glikolu trietylenowego (triethyleneglycol dimethacrylate - TEGDMA), dimetakrylan glikolu etylenowego (ethyleneglycol dimethacrylate - EGDMA), 2,2-bis[4-(2-hydroksy-3-metakryloksypropoksy)fenylo]propan (2,2-bis-[4-(2-hydroxy-3methacrylo-xypropoxy)phenyl]-propane - Bis-GMA), metakrylan 2-hydroksy-etylu (2-hydroxy-ethyl methacrylate - 2-HEMA) i metakrylan tetrahydrofurfurylu (tetrahydrofurfuryl methacrylate - THFMA)). Materiał i metody: Badaniem objęto 262 osoby - studentów stomatologii, uczniów technikum dentystycznego i lekarzy stomatologów oraz pacjentów gabinetów dentystycznych jako grupę porównawczą. U wszystkich badanych wykonano testy płatkowe z monomerami metakrylanowymi i aldehydem glutarowym. Uzyskane wyniki poddano analizie statystycznej $(\mathrm{p}<0,05)$. Wyniki: Najwięcej studentów stomatologii było uczulo-

Funding / Finansowanie: the study was granted by the Medical University, Sofia (contract No. 5-C/2013): "Investigation of the conditions for occurrence of occupational allergy in exposure to methacrylates among students of dentistry, students of dental technician school, assistants and medical personnel involved in the process of education." Contract coordinator: Prof. Angelina Kisselova-Yaneva, D.D.S., Ph.D., D.Sc. 
nych jednocześnie na TEGDMA i G (15,5\%), natomiast najwięcej pacjentów - na EGDMA i G (16,4\%). Współistniejące uczulenie u lekarzy stomatologów występowało znacznie rzadziej niż w powyższych grupach - badani najczęściej byli uczuleni jednocześnie na TEGDMA i G (7,7\%). W grupie najniższego ryzyka uczulenia współistniejącego znaleźli się uczniowie technikum dentystycznego, u których narażenie na aldehyd glutarowy jest mniej prawdopodobne. Wnioski: Studentów stomatologii i pacjentów gabinetów dentystycznych można uznać za grupy ryzyka uczulenia współistniejącego na aldehyd glutarowy i monomery metakrylanowe, lekarzy stomatologów za grupę podwyższonego ryzyka uczulenia współistniejącego na TEGDMA i aldehydy powszechnie stosowane w stomatologii, natomiast uczniów technikum dentystycznego za grupę niskiego ryzyka uczulenia współistniejącego na aldehyd glutarowy i monomery metakrylanowe. Med. Pr. 2016;67(3):311-320

Słowa kluczowe: stomatolodzy, aldehyd glutarowy, współistniejąca alergia kontaktowa, monomery metakrylanowe, studenci stomatologii, uczniowie technikum dentystycznego

Corresponding author / Autorka do korespondencji: Maya Lyapina, Medical University, Faculty of Medicine,

Department of Hygiene, Medical Ecology and Nutrition, 15 Boulevard, Academik Ivan Evstatiev Geshov, 1431 Sofia, Bulgaria, e-mail: saly_grigory@abv.bg

Received: September 30, 2014, accepted: January 12, 2016

\section{INTRODUCTION}

In modern dental practice a great variety of materials, medicines and disinfecting agents are used. Dental materials contain a number of allergens and irritants that may give rise to health issues for patients, to which they have been applied as well as for dental professionals and for dental students during their education $[1,2]$.

Common occupational contact allergens are plastics and resins (methacrylic monomers) and biocides (glutaraldehyde, formaldehyde and formaldehyde releasers). According to Hamann et al. (2004), methacrylates, natural rubber latex proteins, rubber glove allergens, and glutaraldehyde are the predominant allergens in dentistry [3]. Reactions range from cell-mediated contact allergy to urticaria and occupational asthma. The degree of risk might depend on several factors including age, personal susceptibility, total daily exposure, exposure measured over the years, and medication.

Methacrylates serve as a base for acrylic resins [4]. Resin-based dental materials are extensively used today in dentistry - in dentures (bases, liners, tissue conditioners, artificial teeth, temporary restoration, etc.), cavity restorative materials (composites - self and/or light curing), pulpal, cavity and margin sealants, impression materials, resin based cements, dentin bonding agents, orthodontic appliances, habit breaking appliances (nail biting, thumb sucking), etc. [5].

Acrylic resin dentures contain methyl methacrylate (MMA) as residual monomer [6]. The most frequently occurring methacrylates in bonding materials are 2-hydroxy-ethyl methacrylate (2-HEMA) and 2,2-bis-[4-(2-hydroxy-3-methacrylo-xypropoxy) phenyl]-propane (Bis-GMA). Bis-GMA and triethyleneglycol dimethacrylate (TEGDMA) are the most fre- quently occurring methacrylates in composite resins. The main methacrylate of the glass ionomers is 2-HEMA [7]. Acrylic monomers often cross-react, therefore, sensitized individuals are often multiallergic and, accordingly, cannot be exposed to any of the compounds [8-10].

Other important sensitizers in dental practice are the disinfectants, such as glutaraldehyde, formaldehyde and glyoxal [11,12]. A significantly increased risk of occupational sensitization to glutarldehyde and glyoxal among nurses, especially among those exposed in dental practice, was established [13].

Numerous studies confirm the high frequency of sensitization to methacrylates in dental professionals [9,14-17] as well as in patients undergoing dental treatment and exposed to resin-based materials $[18,19]$. Dental students are exposed to the listed above chemical factors right from the beginning of the first years of their education, and in this way they are subjected to the risk of early occupational sensitization.

Results from our previous studies indicate high rates of occupational sensitization to formaldehyde and glutaraldehyde [20] as well as an increased frequency and risk of concomitant sensitization to some methacrylic monomers and formaldehyde among dental students and dental professionals [21]. In the available literature, no data has been found concerning the frequency of concomitant sensitization to methacrylic monomers and glutaraldehyde in dental practice.

\section{Objectives}

The purpose of this study has been to evaluate the frequency and the risk of concomitant sensitization to some methacrylic monomers and to glutaraldehyde among students of dental medicine and those from the dental technician school, and dental professionals. 


\section{MATERIAL AND METHODS}

A total of 262 participants, divided into 4 groups, were included in the study: occupationally exposed to methacrylic monomers and glutaraldehyde dental professionals (dentists, dental nurses and attendants), students of the 3rd-6th year of dentistry from the faculty of dental medicine and students from the dental technician school. A pool of randomly chosen dental patients of different gender, age and occupations who had encountered exposure to methacrylic monomers and glutaraldehyde during dental treatment in various dental clinics served as a control group, the main inclusion criteria being the lack of occupational exposure to the considered substances. Data regarding age and gender characteristics of the studied population is presented in the Table 1.

With respect to the duration of occupational exposure to methacrylates and glutaraldehyde in dental practice, the data is as follows:

0 year for occupationally unexposed patients,

1-4 years for the students of dental medicine,

1-2 years for the students from the dental technician school,

a number (1-50) of years for the occupationally exposed dental personnel.

The study was funded by the Medical University, Sofia and approved by the Medical Ethics Board at the Medical University of Sofia. All participants were informed about the purpose of the study and gave their written informed consent.

\section{Questionnaire survey}

Interviews and detailed and intentionally conducted questionnaire-based survey with an emphasis on family history, suspected or known allergies to a standard set of household or occupational allergens, on history of frequent, recurrent respiratory system infections, and on subjective symptoms, as well as the review of medical documentation were performed.

\section{Skin patch testing}

Skin patch testing with glutaraldehyde and the following methacrylic monomers - methyl methacrylate (MMA), triethyleneglycol dimethacrylate (TEGDMA), ethyleneglycol dimethacrylate (EGDMA), 2,2-bis[4-(2-hydroxy-3-methacryloxypropoxy)phenyl]propane (Bis-GMA), 2-hydroxyethyl methacrylate (2-HEMA), tetrahidrofurfuril metacrylate $(0.2 \% /$ pet, Chemotechnique Diagnostics, Sweden) was performed, according to the Jadassohn and Bloch classical methods for the diagnosis of contact allergy, by placing the allergens in IQ-Ultra hypoallergenic patches of Chemotechnique Diagnostics (IQ Chambers ${ }^{\circledR}$ ).

The lack of anti-allergic medication constituted a mandatory condition before placing the patches and during the testing. Patches with allergens were applied on the back of the tested individuals, reading of the test was performed on 2nd day - $48 \mathrm{~h}$ after the patch test application, several hours after removing the patches, with the control revision on 3rd day $-72 \mathrm{~h}$ after the patch test application.

Interpretation of reaction sites was based on the method recommended by the International Contact Dermatitis Research Group (ICDRG) [22]. The interpretation key based on recommendations by the ICDRG was applied (Table 2).

\section{Statistical methods}

The statistics were calculated by means of SPSS 19.0. Available for cross-tabulation statistics were used: $\mathrm{Chi}^{2}$, Fisher Exact Test for statistical significance, testing of

Table 1. Characteristics of the study groups

Tabela 1. Charakterystyka grup badanych

\begin{tabular}{|c|c|c|c|c|}
\hline \multirow{2}{*}{$\begin{array}{l}\text { Study group } \\
\text { Grupa badana }\end{array}$} & \multirow{2}{*}{$\begin{array}{c}\text { Age } \\
\text { [years] } \\
\text { Wiek } \\
{[\mathrm{w} \text { latach] }} \\
(\mathrm{M} \pm \mathrm{SD})\end{array}$} & \multicolumn{3}{|c|}{$\begin{array}{c}\text { Gender } \\
\text { Płeć }\end{array}$} \\
\hline & & $\begin{array}{l}\text { females } \\
\text { kobiety } \\
{[\mathrm{n}(\%)]}\end{array}$ & $\begin{array}{c}\text { males } \\
\text { mężczyźni } \\
{[n(\%)]}\end{array}$ & $\begin{array}{c}\text { total } \\
\text { ogółem } \\
{[\mathrm{n}]}\end{array}$ \\
\hline Dental patients (control group) / Pacjenci gabinetów stomatologicznych (grupa porównawcza) & $40.89 \pm 18.26$ & $39(79.5)$ & $10(20.5)$ & 49 \\
\hline Students of dental medicine / Studenci stomatologii & $22.44 \pm 2.96$ & $68(61.8)$ & $42(38.2)$ & 110 \\
\hline Dental professionals / Stomatolodzy & $39.56 \pm 9.80$ & $47(72.3)$ & $18(27.7)$ & 65 \\
\hline Total / Ogółem & $39.90 \pm 16.30$ & $183(69.8)$ & $79(30.2)$ & 262 \\
\hline
\end{tabular}

M - mean / średnia, SD - standard deviation / odchylenie standardowe. 
Table 2. Marks for skin patch test results

Tabela 2. Oznaczenia zastosowane do wyników testów płatkowych

\begin{tabular}{ll}
\hline Symbol & \multicolumn{1}{c}{$\begin{array}{c}\text { Meaning } \\
\text { Znaczenie }\end{array}$} \\
\hline$(-)$ & negative reaction / odczyn ujemny \\
+ & doubtful reaction / odczyn wątpliwy \\
+ & $\begin{array}{l}\text { weak positive reaction (non-vesicular) / słaby odczyn dodatni } \\
\text { (bez pęcherzyków) }\end{array}$ \\
++ & $\begin{array}{l}\text { strong positive reaction (oedematous or vesicular) / silny } \\
\text { odczyn dodatni (obrzęk lub pęcherzyki) }\end{array}$ \\
+++ & $\begin{array}{l}\text { extreme positive reaction (ulcerative or bullous) / bardzo silny } \\
\text { odczyn dodatni (wrzodowy lub pęcherzowy) }\end{array}$ \\
IR & irritant reaction / odczyn podrażnieniowy
\end{tabular}

Based on / Na podstawie: International Contact Dermatitis Research Group [22].

the ratio of two probabilistic ones odds ratio (OR). Values of $\mathrm{p}<0.05$ were accepted as statistically significant.

\section{RESULTS}

Distribution by gender was not uniform, with predominance of women in all the investigated groups, but without statistical significance $\left(\mathrm{Chi}^{2}=6.29, \mathrm{p}=0.98\right)$.

Logically, the mean age in the groups of occupationally exposed dental professionals and the occupationally unexposed patients was significantly higher $(\mathrm{p}=0.002)$ as compared to the groups of students (Table 1).

Individuals without a history of allergic pathology prevailed in all the studied groups, with no reliable differences in the overall distribution. No statistical significance concerning the number of subjects with a history of atopy or allergic pathology among the studied groups was found.

Data regarding the frequency of concomitant sensitization to MMA and glutaraldehyde in the investigated groups is summarized in the Table 3.

The highest frequency of concomitant sensitization to MMA and glutaraldehyde was observed in the group of dental patients and the one of dental students, without intra-groups relevant differences. An increased risk of concomitant sensitization to MMA and glutaraldehyde was established confronting the control group of dental patients vs. all the other groups $\left(\mathrm{Chi}^{2}=4.24, \mathrm{p}=0.039\right.$, $\mathrm{OR}=1.595,95 \%$ confidence interval (CI): 1.026-3.741).

Summary of the data concerning the frequency of concomitant sensitization to triethyleneglycol dimethacrylate (TEGDMA) and glutaraldehyde is presented in the Table 4.

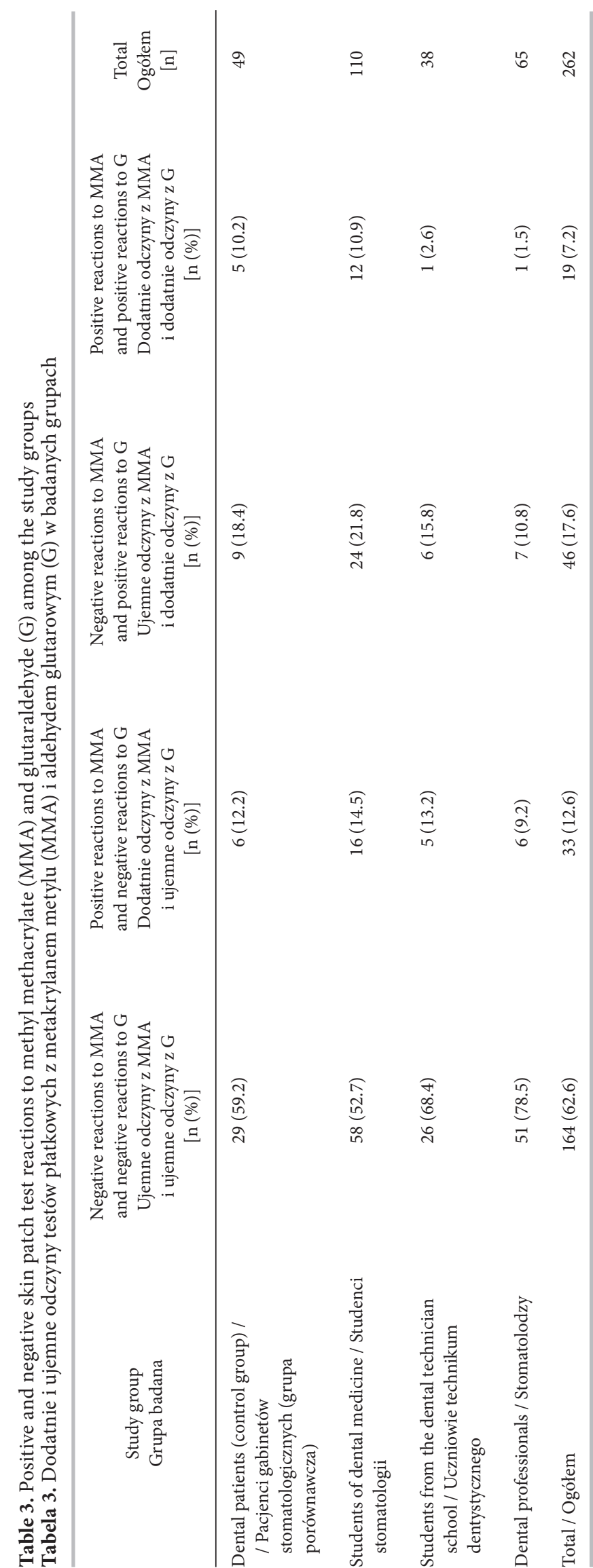




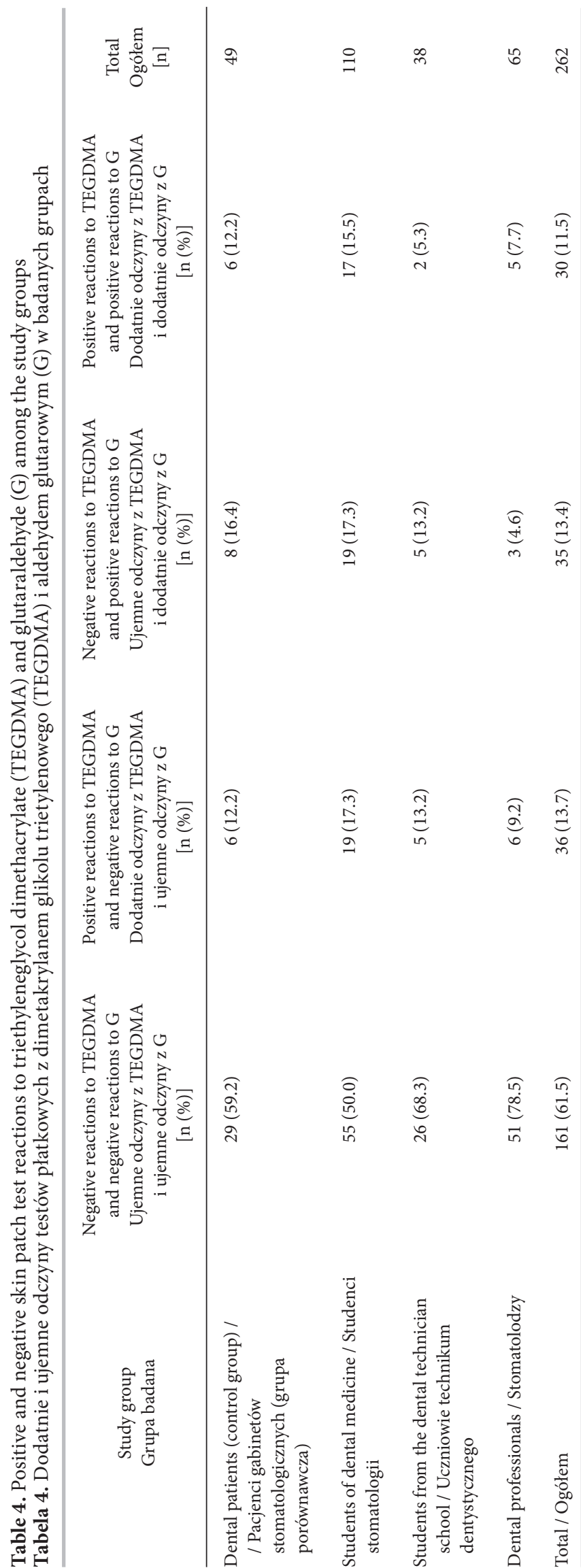

It should be noted that in the group of dental professionals, $62.5 \%$ of the individuals sensitized to glutaraldehyde proved positive skin patch tests to TEGDMA as well. The between-group analysis revealed an increased risk of concomitant sensitization in the groups of dental professionals $\left(\mathrm{Chi}^{2}=13.479, \mathrm{p}<0.001\right.$, $\mathrm{OR}=14.167,95 \% \mathrm{CI}: 2.687-74.703)$ and the one of dental students $\left(\mathrm{Chi}^{2}=4.826, \mathrm{p}=0.028, \mathrm{OR}=2.505\right.$, 95\% CI: $1.092-5.745)$ as compared with the group of students from the dental technician school. An increased risk of concomitant sensitization to MMA and glutaraldehyde was established by means of confronting the control group of dental patients vs. all the other groups $\left(\mathrm{Chi}^{2}=19.165, \mathrm{p}<0.001, \mathrm{OR}=3.677\right.$, 95\% CI: 2.014-6.713).

The results of the skin patch testing to glutaraldehyde and ethyleneglycol dimethacrylate are presented (EGDMA) in the Table 5.

Interestingly, no cases of individuals with concomitant sensitization were diagnosed among the students from the dental technician school. On the other hand, $57.1 \%$ of the group of dental patients manifested concomitant sensitization. An increased risk of concomitant sensitization to glutaraldehyde and to ethyleneglycol dimethacrylate was revealed for the control group of dental patients when confronted vs. the one of students from the dental technician school $\left(\mathrm{Chi}^{2}=12.118\right.$, $\mathrm{p}<0.001, \mathrm{OR}=11,95 \% \mathrm{CI}: 2.498-48.433)$ and vs. all the other groups $\left(\mathrm{Chi}^{2}=13.843, \mathrm{p}<0.001, \mathrm{OR}=3.210\right.$, 95\% CI: 1.705-6.043).

The data on the results from the patch testing to glutaraldehyde and Bis-GMA is presented in the Table 6.

Fifty percent of the individuals from the group of dental patients, and only $12.5 \%$ from the one of dental professionals were concomitantly sensitized to Bis-GMA and glutaraldehyde. The between-group statistical analysis revealed increased frequency of concomitant sensitization in the group of dental patients as compared with the one of dental professionals $\left(\mathrm{Chi}^{2}=3.940, \mathrm{p}=0.047\right)$.

The increased risk of concomitant sensitization to Bis-GMA and glutaraldehyde $\left(\mathrm{Chi}^{2}=9.396, \mathrm{p}=0.002\right.$, $\mathrm{OR}=2.579,95 \% \mathrm{CI}: 1.391-4.781)$ and to 2-hydroxyethyl methacrylate (2-HEMA) and glutaraldehyde $\left(\mathrm{Chi}^{2}=8.353, \mathrm{p}=0.004, \mathrm{OR}=2.498,95 \% \mathrm{CI}: 1.327\right.$ 4.702) was established by means of confronting the control group of dental patients vs. all the other groups.

Data concerning the frequency of concomitant sensitization to tetrahydrofurfuryl methacrylate (THFMA) and glutaraldehyde is presented in the Table 7. 


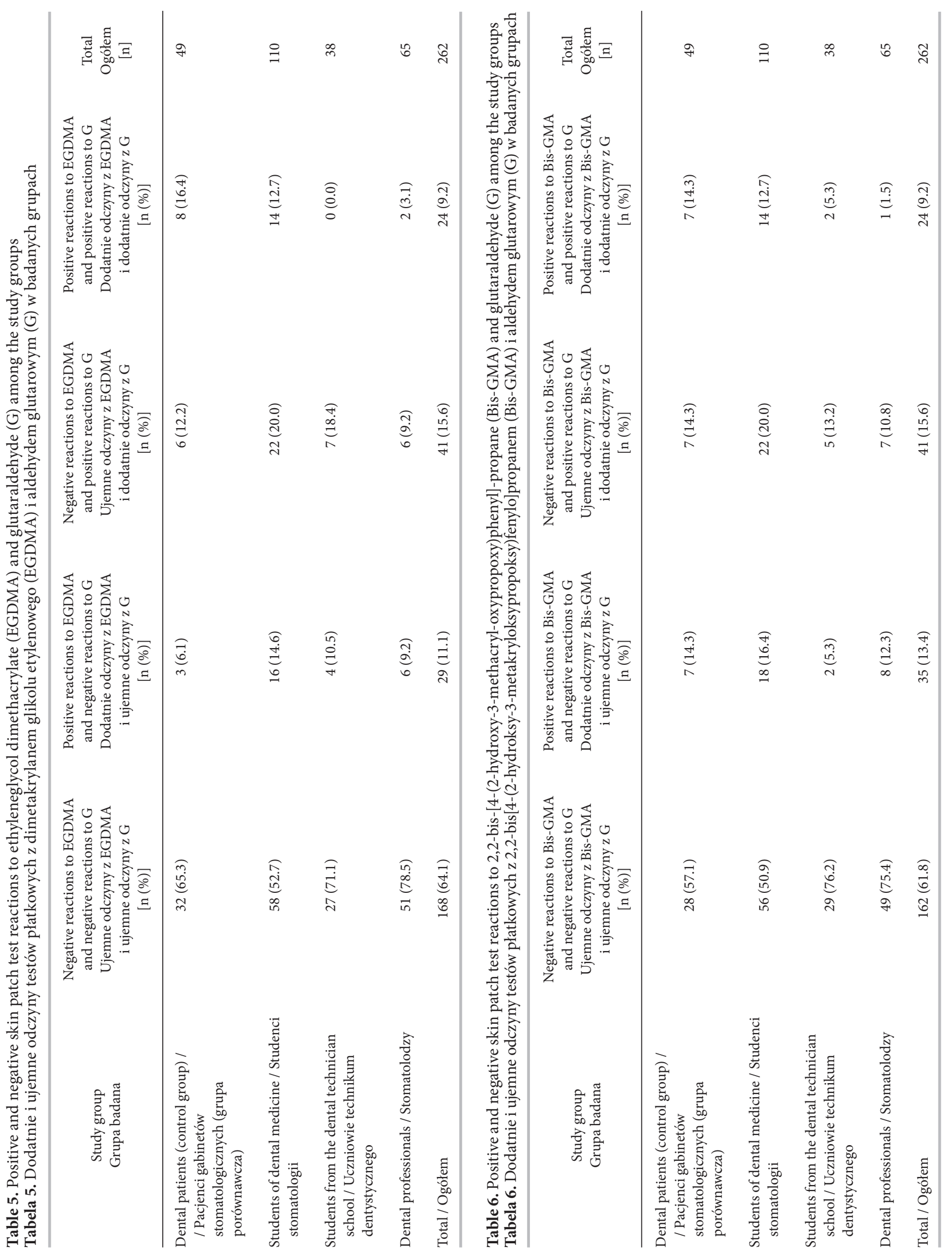


Fifty percent of the individuals from the group of dental patients and the one of dental professionals were sensitized to tetrahydrofurfuryl methacrylate and glutaraldehyde. The between-group statistical analysis revealed the increased frequency and risk of concomitant sensitization in the group of dental patients $\left(\mathrm{Chi}^{2}=4.927\right.$, $\mathrm{p}=0.026, \mathrm{OR}=4.286,95 \% \mathrm{CI}: 1.131-16.238)$ and the one of dental professionals $\left(\mathrm{Chi}^{2}=11.755, \mathrm{p}=0.001, \mathrm{OR}=13\right.$, 95\% CI: 2.330-72.526), as compared with the one of students from the dental technician school. The increased risk of concomitant sensitization to tetrahydrofurfuryl methacrylate and glutaraldehyde was established by means of confronting the control group of dental patients vs. all the other groups as well $\left(\mathrm{Chi}^{2}=19.395\right.$, $\mathrm{p}<0.001, \mathrm{OR}=3.931,95 \%$ CI: $2.087-7.406)$.

\section{DISCUSSION}

Allergic contact dermatitis is a common occupational and environmental issue and may be regarded as being the most frequent manifestation of immunotoxicity in the case of humans. Hundreds of chemicals were shown to cause skin sensitization. Contact allergy is the disease-free state that a skin sensitizer may induce, while allergic contact dermatitis is the disease elicited in an individual with contact allergy [23].

Resin-based dental materials may release methacrylic monomers with potential toxicity and sensitizing properties in the oral environment [24]. Both occupational and non-occupational contact with methacrylic monomers have been reported to cause skin symptoms and induce allergies. Dental professionals are at the occupational risk when handling acrylic monomers manually. Additional problem is imposed by the fact that methacrylates, as small molecules, permeate thin protective disposable gloves [4]. On other hand, dental patients are at the risk of sensitization due to the widespread use of resin-based dental materials with different clinical applications.

Methyl methacrylate is used in orthodontic baseplates and dentures. Triethyleneglycol dimethacrylate is a common monomer in composites, fissure sealants, bonding agents. Ethyleneglycol dimethacrylate is common in composites and bonding agents. 2-Hydroxyetylmetacrylate is an ingredient of dentin-bonding materials and light cured glass-ionomers, cements, and is used as a raw material to be polymerized in paint, adhesive, coating. Bis-GMA is used in composite fillings and fissure sealants. Tetrahydrofurfuryl methacrylates is commonly used in crowns and bridges; as well as in the for- 
mulation of ultraviolet light-curable adhesives, coatings, paints, and printing inks; found in artificial nails [4,5,7].

Some of the most common occupational contact allergens in dental practice are disinfectants, such as glutaraldehyde, formaldehyde, and glyoxal. Among dental nurses, the increased risk for occupational sensitization to glutaraldehyde as well as to glyoxal was established. Kieć-Świerczyńska et al. (1998) studied the frequency of skin sensitization to aldehydes (formaldehyde, glutaraldehyde and glyoxal) in the case of 280 health workers with skin pathology [11]. Allergic contact dermatitis was observed for $22.8 \%$ of them $(85.9 \%$ of them were allergic to only one aldehyde). Formaldehyde is causing sensitization slightly more often (13.9\%), glutaraldehyde (12.4\%), and only $1.9 \%$ of them were allergic to glyoxal [11]. The results were confirmed in the subsequent study $[12,13,25]$. In general, it was established that contact with disinfectants causes sensitization in nearly half of the nurses with contact dermatitis.

In our previous study we established a relatively high frequency of concomitant sensitization to formaldehyde and methacrylate monomers in dental practice [21]. Glutaraldehyde (similarly to formaldehyde) is widely used as a broad-spectrum antimicrobial agent in industrial and consumer products (as an ingredient of disinfecting, sterilizing, household disinfectants, in cosmetics, personal-care products and furniture polish - as a preservative). No data in the available literature was found concerning the manifestation of concomitant sensitization to the other aldehyde that is ubiquitous for the dental working environment - glutaraldehyde. That's why we have conducted this study.

The occupational exposure to methacrylates and glutaraldehyde in dental practice starts as early as during the second year of the practical education in dentistry and lasts throughout the professionally active life of dental personnel. Due to the specificity of their jobs, students from the dental technician school and dental technicians are more likely to be occupationally exposed to methacrylates and to a lesser extent - to glutaraldehyde. Every person could be considered to be exposed to methacrylic monomers containing dental materials and glutaraldehyde - as a dental patient. The first exposure at a dental clinic could happen in the early childhood and could be reiterated many times during the life span of certain individuals. On the other hand, due to the ubiquitous presence of methacrylic monomers and glutaraldehyde, the whole population is under the impact of environmental exposures.

The highest frequency of concomitant sensitization to MMA and glutaraldehyde was established in the group of dental students and in the one of dental patients. For comparison, according to the results from our previous study, the frequency of concomitant sensitization to MMA and to another common for dental practice aldehyde - formaldehyde was again the highest among dental students, especially those from 3 rd-4th year of education.

Data collected in the interviews indicates that during the first years of their educational course, dental students are not sufficiently informed and are unaware to protect themselves using protective gloves at work. This data of ours confirms the statement about the role of the lack of proper protection for the increased frequency of the contact sensitization to MMA (and to some other methacrylic monomers) in the group of students of dental medicine as compared to dental professionals.

Concerning the high frequency of concomitant sensitization to MMA and glutaraldehyde in the group of dental patients - as revealed in this study, we assume the role of exposure from different sources (during dental treatment and long-term environmental exposure), being incognizant and adequately protected.

Interestingly, comparing the frequency of concomitant sensitization to glutaraldehyde and MMA in the group of dental professionals, as observed in this study (1.5\%), and the frequency of concomitant sensitization to formaldehyde and MMA in the same group, as established in our previous study (7.9\%) [21], we could suppose that as far as continuous occupational exposure in dental practice is concerned, the risk of concomitant sensitization to formaldehyde and MMA is higher than to glutaraldehyde and MMA.

The probability of release of TEGDMA from composite resins is high, and the risk of allergies in dental practice has been recognized [26]. The frequency of concomitant sensitization to glutaraldehyde and TEGDMA among all the 262 individuals included in our study has been relatively high $-11.5 \%$, most probably due to the wide application of TEGDMA containing dental materials and the extensive use of glutaraldehyde. The highest frequencies of concomitant sensitization were again established in the groups of dental students and the control one - the group of dental patients.

Having compared the data concerning the frequency of concomitant sensitization to formaldehyde and TEGDMA, the results are similar. Dental professionals seem to be at a higher risk of concomitant sensitization to glutaraldehyde and TEGDMA (7.7\%) than to formaldehyde and TEGDMA (5.3\%) [21]. Based on our results, we assume the increased risk of concomi- 
tant sensitization to TEGDMA and aldehydes that are commonly used in dental practice. We could outline the groups of students of dental medicine and dental patients as most vulnerable groups.

The frequency of concomitant sensitization to glutaraldehyde and to EGDMA and Bis-GMA among the 262 individuals included in this study is $9.2 \%$. Similarly to the results reported above, the highest frequency of concomitant sensitization has been observed in the groups of dental patients and dental students.

It should be pointed that the highest observed frequency of concomitant sensitization to glutaraldehyde and EGDMA - 16.4\% has been in the control group of dental patients. Due to the wide use of EGDMA containing dental composites in contemporary dental practice and the presence of glutaraldehyde in various everyday items, we could once again suppose the role of multiple exposures for the high sensitization rates.

Dental professionals seem to be at a slightly higher risk of concomitant sensitization to THFMA and glutaraldehyde (6.2\%) than to THFMA and formaldehyde (5.6\%) [21]. Just the opposite data was established with regard to the frequency of concomitant sensitization to EGDMA, Bis-GMA and glutaraldehyde (3.1\% vs. $1.5 \%$ ) and the concomitant sensitization to the same methacrylic monomers and formaldehyde (7.9\% vs. 5.6\%) [21]. Moreover, the rate of concomitant sensitization to glutaraldehyde and Bis-GMA has been found to be lowest among the group of dental professionals. These findings once again confirm the statement of the U.S. Department of Health and Human Services (HHS) cited by the American Dental Association (ADA), saying: "Dental sealant exposure to bisphenol A occurs primarily with the use of dental sealants containing bisphenol A dimethacrylate. This exposure is considered to be an acute and infrequent event with little relevance to estimation of general population exposures" [27].

Based on the results achieved, we consider that the group of students from the dental technician school is at a lesser risk of concomitant sensitization to the studied methacrylic monomers and glutaraldehyde. A possible explanation is that the probability of exposure to glutaraldehyde during the course of their education is less likely as compared with dental students. Unfortunately, no available literature has been found to serve as a basis for comparison, nor has it been reported in our own previous studies.

In our view, the above findings deserve attention, and taking into account the widespread exposure to the studied chemical agents - occupational and non- occupational in dental practice, and non-occupational in the residential environment - conducting a large-scale, multicenter survey in the future would be beneficial.

\section{CONCLUSIONS}

The results from our study suggest that dental students and dental patients without the occupational exposure could be outlined as susceptible groups at the risk of concomitant sensitization to glutaraldehyde and methacrylic monomers. An increased risk for concomitant sensitization to TEGDMA and the aldehydes that are commonly used in dental practice could be assumed among dental professionals. We consider the group of students from the dental technician school as a group at a lesser risk of concomitant sensitization to methacrylic monomers and glutaraldehyde.

More efficient risk management and training programs about health and safety at work for dental students as well as limitations of general exposures could be recommended.

\section{REFERENCES}

1. Jacobsen N, Aasenden R, Hensten-Pettersen A. Occupational health complaints and adverse patient reactions as perceived by personnel in public dentistry. Community Dent Oral Epidemiol. 1991;19:155-9, http://dx.doi. org/10.1111/j.1600-0528.1991.tb00132.x.

2. Sinclair NA, Thomson WM. Prevalence of self-reported hand dermatoses in New Zealand dentists. N Z Dent J. 2004;100:38-41.

3. Hamann CP, Rodgers PA, Sullivan KM. Occupational allergens in dentistry. Curr Opin Allergy Clin Immunol. 2004;4:403-9, http://dx.doi.org/10.1097/00130832200410000-00012.

4. Sasseville D. Acrylates in contact dermatitis. Dermatitis. 2012;23(1):6-16, http://dx.doi.org/10.1097/DER.0b0 $13 \mathrm{e} 31823 \mathrm{~d} 1 \mathrm{~b} 81$.

5. Sasseville D. Acrylates. Dermatitis. 2012;23(1):3-5, http://dx.doi.org/10.1097/DER.0b013e31823d5cd8.

6. Keyf FA, Keyf AI. Harmful effects of methylmethacrylate and formaldehyde from acrylic resin denture base materials. Saudi Dent J. 1998;10(1):23-8.

7. Henriks-Eckerman ML, Suuronen K, Jolanki R, Alanko K. Methacrylates in dental restorative materials. Contact Dermatitis. 2004;50(4):233-7, http://dx.doi.org/ 10.1111/j.0105-1873.2004.00336.x.

8. Aalto-Korte K, Henriks-Eckerman ML, Kuuliala O, Jolanki R. Occupational methacrylate and acrylate 
allergy - Cross-reactions and possible screening allergens. Contact Dermatitis. 2010;63(6):301-12, http:// dx.doi.org/10.1111/j.1600-0536.2010.01760.x.

9. Goon AT, Isaksson M, Zimerson E, Goh CL, Bruze M. Contact allergy to (meth)acrylates in the dental series in southern Sweden: Simultaneous positive patch test reaction patterns and possible screening allergens. Contact Dermatitis. 2006;55(4):219-26, http://dx.doi.org/10.1111/ j.1600-0536.2006.00922.x.

10. Kanerva L. Cross-reactions of multifunctional methacrylates and acrylates. Acta Odontol Scand. 2001;59(5): 320-9, http://dx.doi.org/10.1080/000163501750541200.

11. Kieć-Świerczyńska M, Kręcisz B, Krysiak B, Kuchowicz E, Rydzyński K. Occupational allergy to aldehydes in health care workers. Clinical observations. Experiments. Int J Occup Med Environ Health. 1998;11(4):349-58.

12. Ravis SM, Shaffer MP, Shaffer CL, Dehkhaghani S, Belsito DV. Glutaraldehyde-induced and formaldehyde-induced allergic contact dermatitis among dental hygienists and assistants. J Am Dent Assoc. 2003;134(8):1072-8, http://dx.doi.org/10.14219/jada.archive.2003.0321.

13. Kieć-Świerczyńska M, Kręcisz B. [Causes of occupational allergy in dental nurses. An analysis based on the material collected at the Institute of Occupational Medicine, Łódź]. Med Pr. 2000;51(2):145-9. Polish.

14. Aalto-Korte K, Alanko K, Kuuliala O, Jolanki R. Methacrylate and acrylate allergy in dental personnel. Contact Dermatitis. 2007;57(5):324-30, http://dx.doi.org/10.1111/ j.1600-0536.2007.01237.x.

15. Alanko K, Susitaival P, Jolanki R, Kanerva L. Occupational skin diseases among dental nurses. Contact Dermatitis. 2004;50(2):77-82, http://dx.doi.org/10.1111/ j.0105-1873.2004.00304.x.

16. Prasad Hunasehally RY, Hughes TM, Stone NM. Atypical pattern of (meth)acrylate allergic contact dermatitis in dental professionals. Br Dent J. 2012;213:223-4, http:// dx.doi.org/10.1038/sj.bdj.2012.776.

17. Scott A, Egner W, Gawkrodger DJ, Hatton PV, Sherriff M, van Noort R, et al. The national survey of adverse reactions to dental materials in the UK: A preliminary study by the UK Adverse Reactions Reporting Project. Br Dent J. 2004;196(8):471-7, http://dx.doi.org/10.1038/ sj.bdj.4811176.
18. Gawkrodger DJ. Investigation of reactions to dental materials. Br J Dermatol. 2005;153(3):479-85, http://dx.doi. org/10.1111/j.1365-2133.2005.06821.x.

19. Tillberg A, Stenberg B, Berglund A. Reactions to resinbased dental materials in patients-type, time to onset, duration, and consequence of the reaction. Contact Dermatitis. 2009;61(6):313-9, http://dx.doi.org/10.1111/ j.1600-0536.2009.01590.x.

20. Lyapina M, Krasteva A, Dencheva M, Tzekova M, Deliverska M, Kisselova-Yaneva A. Prevalence and risk factors of occupational contact dermatitis to formaldehyde and glutaraldehyde and their co-reactivity in dental professionals. Int J Biomed. 2013;3(2):84-9.

21. Lyapina M, Dencheva M, Krasteva A, Tzekova M, Kisselova-Yaneva A. Concomitant contact allergy to formaldehyde and methacrylic monomers in students of dental medicine and dental patients. Int J Occup Med Environ Health. 2014;27(5):797-807, http://dx.doi.org/10.2478/ s13382-014-0314-4.

22. Fregert S. Manual of contact dermatitis. On behalf of the International Contact Dermatitis Research Group and the North American Contact Dermatitis Group. 2nd ed. Copenhagen: Munksgaard Publishers; 1981.

23. Dietert RR, Luebke RW, editors. Immunotoxicity, immune dysfunction, and chronic disease. New York: Springer; 2011, http://dx.doi.org/10.1007/978-1-61779-812-2.

24. Van Landuyt KL, Nawrot T, Geebelen B, de Munck J, Snauwaert J, Yoshihara K, et al. How much do resinbased dental materials release? A meta-analytical approach. Dent Mater. 2011;27(8):723-47, http://dx.doi. org/10.1016/j.dental.2011.05.001.

25. Kieć-Świerczyńska M, Kręcisz B. Occupational skin diseases among the nurses in the region of Łódź. Int J Occup Med Environ Health. 2000;13(3):179-84.

26. Seiss M, Langer C, Hickel R, Reichl FX. Quantitative determination of TEGDMA, BHT, and DMABEE in eluates from polymerized resin-based dental restorative materials by use of GC/MS. Arch Toxicol. 2009;83(12):1109-15, http://dx.doi.org/10.1007/s00204-009-0470-7.

27. American Dental Association. ADA positions and statements: Bisphenol $\mathrm{A}$ and dental materials [Internet]. Chicago: The Association; 2012 [cited 2014 Sep 30]. Available from: http://www.west-end-dental.com/images/ ADABisphenolArticle.pdf.

This work is available in Open Access model and licensed under a Creative Commons Attribution-NonCommercial 3.0 Poland License / Ten utwór jest dostępny w modelu open access na licencji Creative Commons Uznanie autorstwa - Użycie niekomercyjne 3.0 Polska - http://creativecommons.org/ licenses/by-nc/3.0/pl/deed.en. 